\title{
Isolation and Characterization of Expansin Genes in a Halophyte, Suaeda japonica
}

\author{
Soong-Taek Hwang, Suk Kyu Kim, Jong Gil Na, Jeom Sook Lee and Dongsu Choi*
}

Department of Biology, Kunsan National University, Gunsan 573-701, Korea

Received November 30, 2012 /Revised December 14, 2012 /Accepted December 17, 2012

\begin{abstract}
Halophytes are unique land plants that are capable of thriving in a high salt environment. They are attracting public attention due to their ability to synthesize bioactive substances such as UV protectants or antioxidizing agents. To achieve unaffected growth under high salinity, halophytes may take advantage of the activities of cell growth factors such as expansins. Expansins are well-known cell wall proteins that are responsible for cell enlargement. They loosen cell walls, thereby contributing to actual plant growth. This study aimed to identify positive roles of expansins in the growth of halophytes. Three expansin cDNA clones were isolated from seedlings of Suaeda japonica. Comparing the deduced amino acid sequences of the expansin genes of $S$. japanica with those of other plant species suggested that the CDNA clones isolated from $S$. japonica belong to the EXPA (a-expansin) gene family. A phylogenetic tree based on the deduced amino acid sequences revealed that the expansins of $S$. japonica share a close evolutionary relationship with those of strawberry (Fragaria ananassa) and jujube (Ziziphus jujuba), both of which are woody dicots. SjEXPAs did not show any remarkable change in the gene expression level in different $\mathrm{NaCl}$ concentrations, providing a clue to the unaffected seedling growth of $S$. japonica in a high-salt environment. In conclusion, the present study presents the first report of expansin genes from halophytes and suggests a putative role for these genes in plant growth under high salinity.
\end{abstract}

Key words : Suaeda japonca, halophyte, expansin, growth, $\mathrm{NaCl}$

\section{서 론}

식물 세포벽은 다당류인 cellulose와 hemicellulose 간의 수 소결합으로 복잡하게 얽혀있는 견고한 기본 구조를 가지고 있다. 따라서 식물 세포의 생장과 분열이 일어나기 위하여 우 선 세포벽의 구조가 느슨하게 풀려야 한다[7, 10,11]. Expansin 은 식물 고유의 세포벽 단백질로서 식물 세포벽을 느슨하게 함으로써 식물세포가 신장하도록 유도하므로 식물의 생장에 있어서 반드시 필요한 단백질이라고 할 수 있다[11]. Expansin 은 산성 조건 하에서 C-말단 부위를 cellulose에 고정한 채 $\mathrm{N}$ - 말단 부위에 있는 활성부위를 이용하여 cellulose와 hemicellulose 사이의 수소결합을 분쇄함으로써 세포벽을 느슨하 게 하고 팽압의 증가에 따라 세포가 팽창할 수 있도록 한다. Expansin은 단백질의 구조에 따라 EXPA, EXPB, EXLA 및 EXLB의 4개의 subfamily로 나뉜다[7, 14].

Expansin은 세포벽의 물리적 성질에 변화를 줌으로써 식물

\footnotetext{
*Corresponding author

Tel : +82-63-469-4583, Fax : +82-63-463-1560

E-mail : choid@kunsan.ac.kr

This is an Open-Access article distributed under the terms of the Creative Commons Attribution Non-Commercial License (http://creativecommons.org/licenses/by-nc/3.0) which permits unrestricted non-commercial use, distribution, and reproduction in any medium, provided the original work is properly cited.
}

생장과 발달 전반에 걸쳐 영향을 준다. 특히 벼의 일종인 부도 (deepwater rice)에서 expansin 유전자가 절간의 생장과 깊이 관련되어 있다는 사실이 밝혀지면서 expansin이 식물생장을 직접적으로 유도하는 중요한 역할을 수행할 것이라는 가설이 지지를 얻고 있다[19, 20]. Expansin은 또한 뿌리의 생장과 발 달에도 직접적으로 관여하는 것으로 알려져 있다. 애기장대의 expansin 유전자 중 AtEXPA7와 AtEXPA18의 발현이 뿌리털 형성과 밀접하게 연관되어 있다는 것이 확인된 바 있으며[2], 대두 유식물체의 뿌리를 사용한 실험에서는 오직 뿌리의 생장 부위에서만 expansin 유전자가 강하게 발현된다는 것이 확인 되었다[17]. 토마토, 벼, 바나나 같이 다양한 식물 종에서 expansin은 세포벽의 연화 과정에 영향을 미치거나, 열매가 발 달하는 동안 열매의 크기가 증가하는데 중요한 역할을 하기도 한다 $[1,4,5,6,13,25]$.

최근에는 세포의 팽창(expansion), 열매 조직의 연화 (softening), 탈리(abscission), 발아, 스트레스 반응 및 기생 관 계(parasitism) 등의 다양한 생리 및 생태적 현상에 있어서 expansin의 기능에 대한 연구가 수행되고 있다. 일련의 연구 결 과에 따르면 expansin의 활성이 호르몬 작용에 의하여 영향을 받는 것으로 나타났다[3]. 이와 같이 expansin은 식물의 생장 과 분화에 필요한 세포벽의 변화를 유도하는 중요한 요소라고 할 수 있다.

염생식물은 일반 육상식물이 생장할 수 없을 정도로 토양의 
염분농도가 높은 바닷가, 호숫가 및 암염이 농축되어 있는 내 륙의 토양환경에서 효과적으로 생장할 수 있는 식물을 말한 다. 생육지의 수분 함량에 따라서 건염생식물과 습염생식물로 구분하지만 모두 세포 내에 많은 용질을 함유하고 있어 삼투 압이 높기 때문에 토양의 염분농도가 높은 경우에도 물을 흡 수할 수 있다. 우리나라에 자생하는 염생식물에는 퉁틍마디 (Salicornia herbacea), 갯질경이(Limonium tetragonum), 통보리 사초(Carex kobomugr), 나문재(Suaeda asparagoides), 칠면초 (Suaeda japanica) 및 해홍나물(Suaeda maritima) 등이 있다[21].

염생식물은 염분이 많은 해안의 염생습지에서 서식하면서 먹이 연쇄의 기초 생산자 역할을 하는 식물이다. 이들은 세립 질 토양 입자에 뿌리를 단단히 내리므로 조류로 인한 해안 침식 활동을 억제하며, 조간대의 염분농도에 따라 서식지를 이동하는 특징을 가지므로 염생식물 서식지의 분포 변화를 통한 조간대의 환경변화를 파악할 수 있는 적절한 환경 요소 로도 이용되고 있다[16]. 최근 들어 염생식물이 오염물질의 정 화 능력이나 다양한 약리적인 효과를 가지고 있는 것으로 밝 혀져 관심의 대상이 되고 있으며 재배를 통한 이용 가능성이 날로 증가하고 있다[16, 18, 21].

칠면초는 명아주과 나문재속에 속하는 일년생 초본식물로 Salicornia와 Atriplex와 더불어 높은 염분 농도에서 생장할 수 있는 대표적인 내염성 식물로서 한국 서해안 조간대에 광범위 하게 분포하고 있으며 중국-일본 간의 해안 식생을 대표하는 종이다[9]. 나문재속 식물에 대한 국내외 연구는 주로 생리적 특성, 분포특성, 생육에 미치는 환경요인이나, 지역에 따른 형 태적 차이 등에 집중되고 있으며 분자생물학적 연구는 시작단 계에 있다[22].

최근에는 expansin이 염분을 비롯한 각종 스트레스 반응에 밀접하게 관련되어 있다는 연구 결과들이 보고되고 있다[12, 23, 24]. Expansin 과다발현 애기장대를 이용한 스트레스 실험 에서 염분 스트레스와 $\mathrm{ABA}$ 를 처리한 곳에서의 유식물의 크기 와 야생형의 유식물의 크기가 차이가 없는 것이 확인되었다 [12]. 내염성 옥수수를 이용한 연구에서 염분농도에 따른 옥수 수 expansin 단백질의 발현양상을 분석한 결과, 염분 처리구와 대조구에서 모두 expansin이 발현될 뿐만 아니라 내염성 옥수 수에서 야생형 옥수수보다 더 많은 양의 expansin이 발현된다 는 사실이 보고된 바 있다[24].

본 연구에서는 분자생물학적인 연구가 미진한 국내산 염생 식물 중에서 칠면초를 재료로 expansin 유전자를 분리하여 특 성을 밝히는 한편, 토양환경의 염분 농도에 따른 생장정도와 expansin 유전자 발현양상과의 연관성을 확인하고자 하였다.

\section{재료 및 방법}

식물재료

본 실험에서는 명아주과 나문재속의 칠면초(Suaeda japon- ica Makino)를 사용하였다. Expansin cDNA 합성을 위한 RNA 분리용 식물 재료로는 전북 군산시 옥서면 선연리 염습 지에서 채취한 평균 초장 $10 \mathrm{~cm}$ 인 칠면초 유식물을 사용하였 으며, 발아 및 스트레스 처리 실험을 위한 재료로는 농어촌공 사 김제지사에서 분양받은 칠면초 종자(2010년 채집)를 사용 하였다.

\section{$\mathrm{NaCl}$ 농도 별 배양}

칠면초 종자를 $70 \%$ 에탄올과 $2 \% \mathrm{NaOCl}$ 로 표면 소독한 후 각각 $0,1,2,5,10,20 \mathrm{ppt}$ (part per thousand)의 $\mathrm{NaCl}$ 을 함유 한 $1 / 2 \mathrm{MS}$ 배지에서 2 주간 발아 및 배양하여 염분농도별로 칠면초 유식물의 생장을 관찰하고 total RNA 분리에 사용하 였다.

\section{RNA 추출 및 Full-length cDNA 합성}

cDNA 합성을 위한 total RNA는 TRI Reagent (Sigma, USA)를 이용하여 칠면초 유식물로부터 추출하였다. 칠면초 total RNA에서 expansin 유전자의 cDNA를 합성하기 위해 CapFishing full-length cDNA premix kit (Seegene, Korea)를 사용하였다. Expansin 유전자의 기관별 발현과 스트레스 조건 에서의 발현양상 분석을 위해 필요한 1st strand cDNA는 PrimeScript $^{\mathrm{TM}}$ 1st strand cDNA synthesis kit (TAKARA, Japan)를 사용하여 합성하였다. cDNA 합성의 주형으로는 2 $\mu \mathrm{g}$ 의 total RNA를 사용하였으며, oligo dT primer를 사용하여 1 st strand $\mathrm{cDNA}$ 를 합성하였다. Expansin 유전자 cDNA의 PCR 증폭을 위하여 Rose et al. (1997)과 Kim et al. (2000)이 사용한 expansin의 보존적 공통염기서열을 분석하여 만든 degenerate primer 5'-GSNCAYGCNACNTTYTAYGGNG-3, $5^{\prime}$-YTGCCARTTYTGNCCCCARTT-3'을 각각 forward와 reverse primer로 사용하였고[15, 25], PCR 효소로는 TAKARA EX Taq ${ }^{\mathrm{TM}} \mathrm{DNA}$ 중합효소(TAKARA, Japan)를 사용하였다. 이 결과 확보한 partial cDNA를 토대로 full-length cDNA를 합성 하기 위해 $5^{\prime} \mathrm{RACE}$ PCR과 $3^{\prime} \mathrm{RACE} \mathrm{PCR을} \mathrm{수행하였다.} 5^{\prime}$ RACE PCR에 사용한 주형은 CapFishing Full-length cDNA Premix kit를 이용해 합성한 cDNA를 사용하였다. Full-length $\mathrm{CDNA}$ 를 합성하기 위한 다른 방법으로 5'-Full RACE Core set (TAKARA, Japan)을 이용한 inverse PCR을 수행하였다. Primer는 제조사의 제작방법을 이용하여 제작하였다(Table 1).

Semi-quantitative RT-PCR의 대조구(internal control)로 사 용하기 위하여 GenBank 데이터베이스(http://www.ncbi. nim.nih.gov/)로부터 나문재 및 해홍나물의 actin 유전자의 염 기서열을 확인하고 이들의 공통염기서열을 파악하였다. 공통 염기서열을 토대로 칠면초 actin 유전자의 cDNA를 합성하기 위해 5'-GATCTTGCTGGTCGTGATCT-3, 5'-CTCCAATCC AGACACTGTAT- $3^{\prime}$ 을 각각 forward와 reverse primer로 제 작하였으며 TAKARA EX Taq ${ }^{\mathrm{TM}} \mathrm{DNA}$ 중합효소를 사용하여 
Table 1. Primer sequences for inverse PCR

\begin{tabular}{cc}
\hline Primers & Primer sequences $\left(5^{\prime}{ }^{\prime}{ }^{\prime}\right)$ \\
\hline EXP-RT-Primer-1 & (P)GACCAAATTGCCAA \\
EXP-RT-Primer-2 & $($ P)GGAATTGTGCACCAG \\
SjEXPA1-A1 & CGAAGTTCGTAGCATGAACC \\
SjEXPA1-A2 & GATTTCCGTATCCACATGCC \\
SjEXPA1-S1 & TATCGTGCTGGAATTGTCC \\
SjEXPA1-S2 & CGGTCACTCCTACTTCAACT \\
SjEXPA2-A1 & CGAAGACACCATTGTGGGTC \\
SjEXPA2-A2 & GCCTTGACTATACAAGTTCC \\
SjEXPA2-S1 & ATACGGTTCACCATAAACGG \\
SjEXPA2-S2 & AGATGGCAAGCCATGTCAAG \\
SjEXPA3-A1 & GCACGAAAGTTCGTAGCATG \\
SjEXPA3-A2 & AAGTCTCCATATCCGCAAGC \\
SjEXPA3-S1 & TACCGTGCCTAAGAACTGGT \\
SjEXPA3-S2 & CGCAGTTGTTCGATTAAGGG \\
\hline
\end{tabular}

Table 2. Primer sequences to amplify cDNAs for expansin genes

\begin{tabular}{ccc}
\hline Gene names & Primers & Primer sequences $\left(5^{\prime}-3^{\prime}\right)$ \\
\hline \multirow{2}{*}{ SjEXP1 } & SjEXP1-F-1 & ACTTAGCACGGCCTCGTTCA \\
& SjEXP1-R-1 & CCCATTTAGGAGCGAATTGC \\
SjEXP2 & SjEXP2-F-1 & GGCATCAAACTTCCCCTAAA \\
& SjEXP2-R-1 & TGGGAGTTCAACAATTGCAT \\
SjEXP3 & SjEXP3-F-1 & GAGGGTGGTCAATTCTAAGA \\
& SjEXP3-R-1 & CATTGATCAATTCCGAGATC \\
\hline
\end{tabular}

칠면초 actin cDNA를 증폭하였다.

$\mathrm{CDNA}$ 클로닝과 염기서열분석

$\mathrm{PCR}$ 을 통하여 합성된 expansin 및 actin 유전자의 $\mathrm{cDNA}$ 는 pGEM T-easy vector system (Promega, USA)을 이용하여 plasmid에 삽입하였다. 완성된 plasmid를 열충격 방법으로 대 장균 $\mathrm{DH} 5 \mathrm{a}$ 에 도입한 후, 항생제 screening을 거쳐 배양한 다 음 Axyprep plamid miniprep kit (Axygen, USA)를 사용하여 plasmid를 추출하였다. 추출한 plasmid는 전기영동으로 분리 하고 염기서열을 확인하였다.

Expansin 유전자의 발현양상 분석을 위한 semi-quantitative RT-PCR

칠면초의 expansin 유전자의 발현양상 분석을 위한 주형으 로 PrimeScript ${ }^{\mathrm{TM}} 1$ st strand cDNA synthesis kit를 사용하여 합성한 cDNA를 사용하였으며, semi-quantitative RT-PCR 반 응을 위하여 Table 2의 primer를 사용하였다. TAKARA EX $\mathrm{Taq}^{\mathrm{TM}} \mathrm{DNA}$ 중합효소를 사용하여 $98^{\circ} \mathrm{C} 10$ 초, $55^{\circ} \mathrm{C} 30$ 초 그리 고 $72^{\circ} \mathrm{C} 30$ 초의 25,30 또는 35 cycle로 $\mathrm{PCR}$ 을 수행하였다. 각 유전자의 발현량 비교에 적절한 PCR cycle 수는 반복 실험 을 통하여 결정하였다[8].

기관별 및 염분 농도별 expansin 유전자 발현양상 분석을
위한 semi- quantitative RT-PCR 에 동일한 양의 1st strand $\mathrm{CDNA}$ 를 사용하였다는 것을 보여주기 위한 대조구 유전자로 는 칠면초 actin 유전자 염기서열을 사용하였다.

\section{결 과}

칠면초 Expansin cDNA 분리, 염기서열 및 아미노산서열 분석

칠면초 expansin 유전자의 cDNA를 분리하기 위해 degenerate primer를 사용하여 PCR을 수행하였다. 여기에서 확보한 CDNA를 주형으로 하여 5' RACE PCR과 $3^{\prime} \mathrm{RACE} \mathrm{PCR을} \mathrm{수}$ 행한 결과 3종의 full-length cDNA 클론을 확보하였으며 각각 SjEXPA1, SjEXPA2 및 SjEXPA3로 명명하였다. 염기서열을 분 석한 결과 SjEXPA1, SjEXPA2 및 SjEXPA3는 각각 930개, 1391 개 및 1214 개의 염기로 이루어져 있으며, 각각 253개, 257개 및 247 개의 아미노산으로 이루어진 단백 질을 암호화하는 것 을 확인하였다.

\section{칠면초 expansin 단백질 구조 분석}

칠면초의 expansin 단백질 3종이 EXPA, EXPB, EXLA 및 EXLB 단백질군 중에서 어디에 속하는지 알기 위해 유추한 아미노산서열을 이용하여 단백질 구조분석을 수행하였다. 
칠면초 expansin 아미노산서열을 이용하여 유사도가 비슷 한 다른 종의 expansin 아미노산서열을 GenBank 데이터베이 스에서 선별하였다. 다른 종의 expansin 아미노산서열은 애기 장대(AtEXPA1), 딸기(FaEXPA2), 고사리(MqEXPA1), 담배 (NtEXPA1), 옥수수(ZmEXPA1), 이끼(PpEXPA5), 토마토

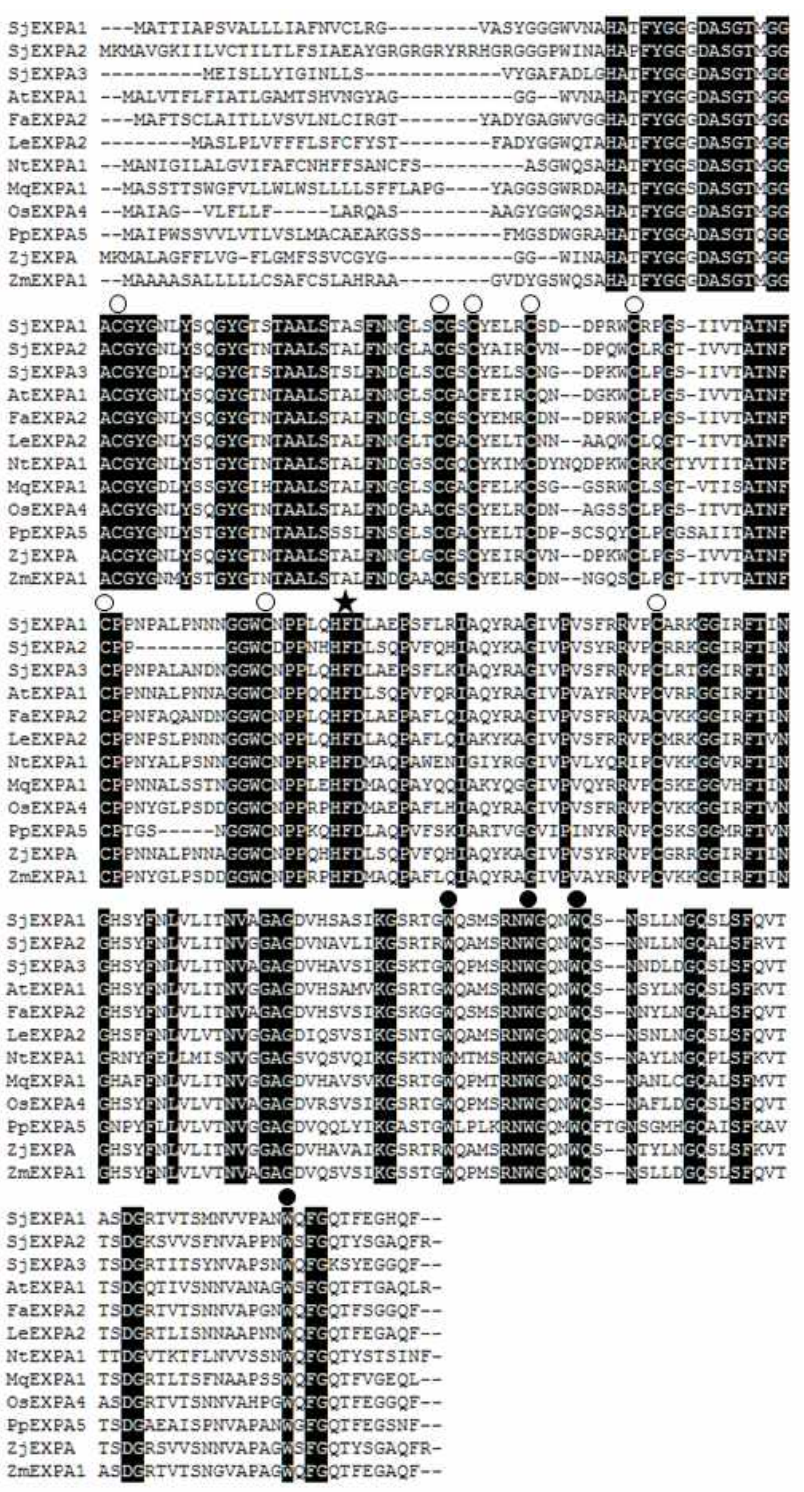

Fig. 1. Comparison of expansin amino acid sequences among 10 plant species suggesting that SjEXPs are classified into EXPA (a-expansin) family [SjEXPA1, SjEXPA2, SjEXPA3, AtEXPA1 (NP_177112), FaEXPA2 (AAF21101), LeEXPA2 (NP_001234165), NtEXPA1 (AAC96077), MqEXPA1 (AAF17570), OsEXPA4 (AAL24481), PpEXPA5 (AAN08123), ZjEXPA (ACK43223) and ZmEXPA1 (NP_001105040)]. Amino acid sequence alignment was performed using the MEGA5 program. Conserved cysteine $(\mathrm{C})$, tryptophan $(\mathrm{W})$ residues and His-Phe-Asp (HFD) domain are marked by circles, dark circles and asterisk, respectively.
(LeEXPA2), 벼(OsEXPA4) 및 대추나무(ZjEXPA)에서 확보하 였다. 상기 9종의 expansin과 칠면초 expansin의 아미노산서 열을 비교한 결과, 칠면초 expansin 단백질에 시스테인(C), 트 립토판(W) 및 히스티딘-페닐알라닌-아스파르트산(HFD) domain이 존재함을 확인하였다(Fig. 1).

아미노산서열 비교를 통한 계통수 작성 결과, 칠면초 expansin 중 SjEXPA1과 SjEXAP3는 딸기의 expansin (FaEXPA2)과, SjEXPA2는 대추나무 expansin (ZjEXPA)과 유 사도가 높은 것으로 나타났다(Fig. 2).

\section{칠면초 actin cDNA 클로닝 및 염기서열 분석}

Expansin의 발현양상 분석에 대조구 유전자로 사용할 actin 유전자를 GenBank 데이터베이스에서 검색한 결과, 칠면초에 서는 actin 유전자가 보고된 바 없으므로 같은 명아주과 염생 식물인 해홍나물(Suaeda maritima)과 나문재(Suaeda glauca)의 actin 유전자의 염기서열을 확보하였다. 두 식물의 actin 유전 자 염기서열을 비교하여 두 유전자 모두에 공통적으로 존재하 는 염기서열을 찾아 제작한 primer로 PCR 증폭하여 칠면초의 actin 유전자 cDNA를 합성하였다. 염기서열 분석 결과 칠면초 actin 유전자는 해홍나물과 나문재의 actin 유전자와 염기서열 이 매우 유사함을 확인하였다(Fig. 3).

\section{기관별 expansin 발현양상 비교 분석}

3종의 칠면초 expansin cDNA의 염기서열을 분석하여 각 expansin 유전자에 특이적인 염기서열로 primer를 각각 제작 하여 semi-quantitative RT-PCR을 수행하였다. 그 결과 모든 expansin 유전자가 유식물의 지상부에서 발현되며, 잎에서는 $S j E X P A 1$ 과 SjEXPA2의 발현이 강한 반면 SjEXPA3은 발현이 약함을 확인하였다. 한편, 뿌리에서는 SjEXPA1과 SjEXPA2의

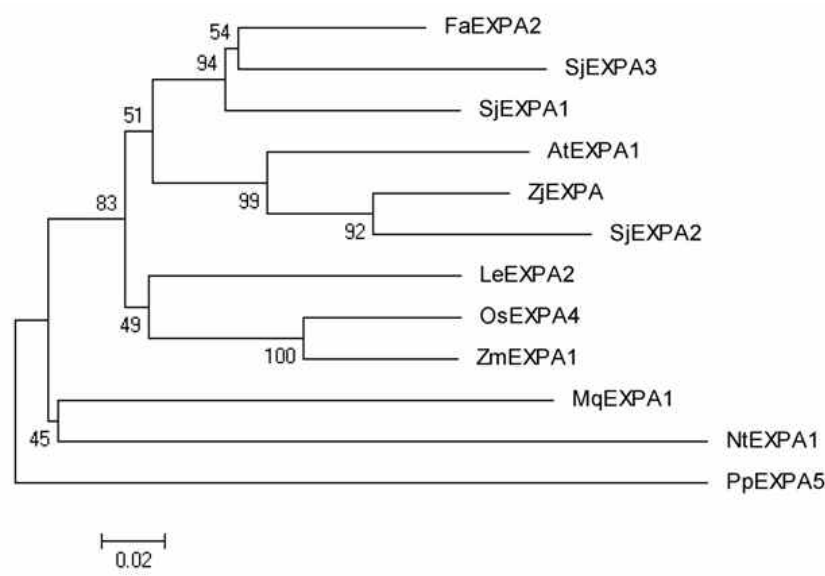

Fig. 2. Phylogenetic tree of expansin proteins. The full-length amino acid sequences of EXPAs were obtained from the GenBank database. The tree was constructed with the MEGA5 program. Bar below diagram represents genetic distance. 


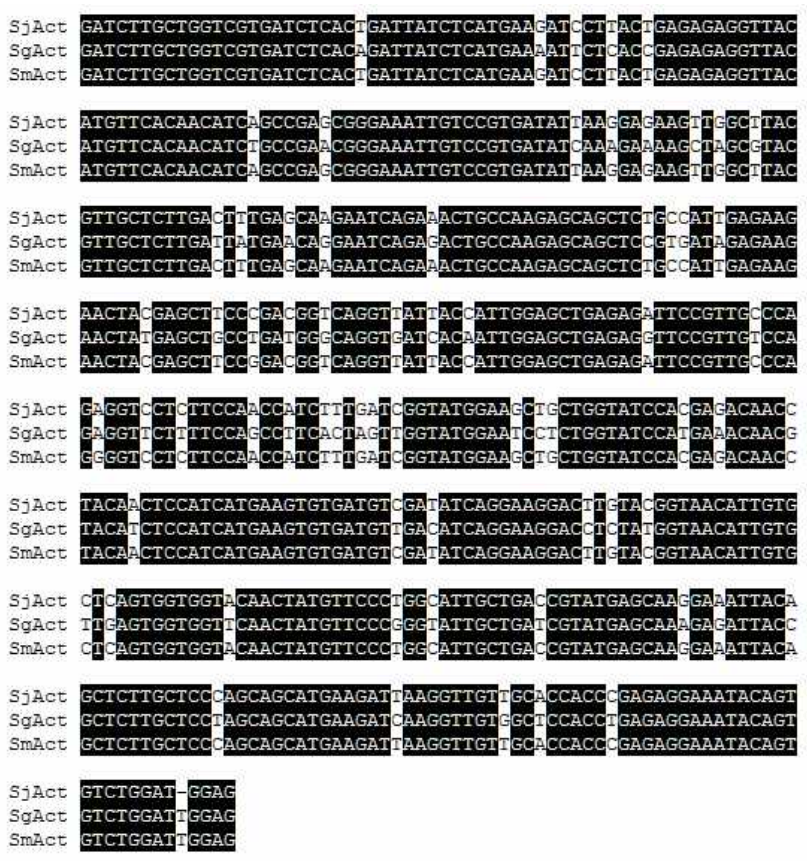

Fig. 3. Comparison of actin cDNA nucleotide sequences among halophyte of goosefoot family [SjAct (Suaeda japonica), SgAct (Suaeda glauca) and SgAct (Suaeda maritima)] suggesting that $S j A c t$ belongs to actin gene family.

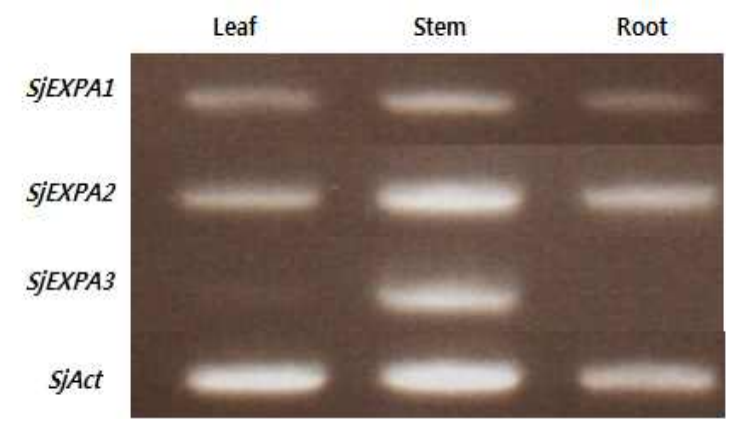

Fig. 4. Expression of Suaeda japonica expansin genes in different plant organs (leaf, stem and root). Semi-quantitative RT-PCR was conducted with SjAct as an internal control. Results are representative of those from repeated experiments.

발현이 강하며, SjEXPA3은 전혀 발현되지 않았다(Fig. 4).

유식물의 줄기를 세분화하여 칠면초 expansin의 발현양상을 비교한 결과 줄기에서는 모든 expansin이 발현되었으며, 잎에 서는 SjEXPA2가 강하게 발현되는 것을 확인하였다(Fig. 5).

\section{$\mathrm{NaCl}$ 농도별 칠면초 생장 변화 분석}

$28^{\circ} \mathrm{C} 24$ 시간 연속광 조건의 배양기에서 각각 $0 \mathrm{ppt}, 1 \mathrm{ppt}$, $2 \mathrm{ppt}, 5 \mathrm{ppt}, 10 \mathrm{ppt}$ 및 $20 \mathrm{ppt}$ 의 $\mathrm{NaCl}$ 을 함유한 $1 / 2 \mathrm{MS}$ 배지 에서 2주간 배양한 칠면초 유식물의 생장도를 측정하였다. 실 험에 사용한 $\mathrm{NaCl}$ 농도 범위 내에서 칠면초의 생장도는 큰

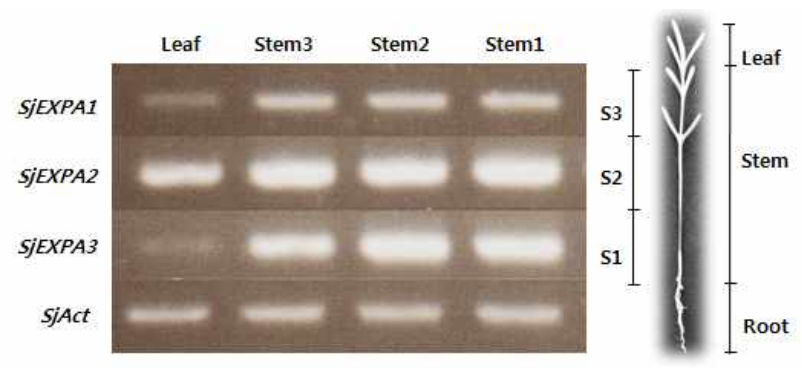

Fig. 5. Expression of Suaeda japonica expansin genes in different plant organs [leaf, stem3 (S3), stem2 (S2) and stem1 (S1)]. Semi-quantitative RT-PCR was conducted with SjAct as an internal control. Stem was dissected along the shoot axis as shown on right panel. Results are representative of those from repeated experiments.

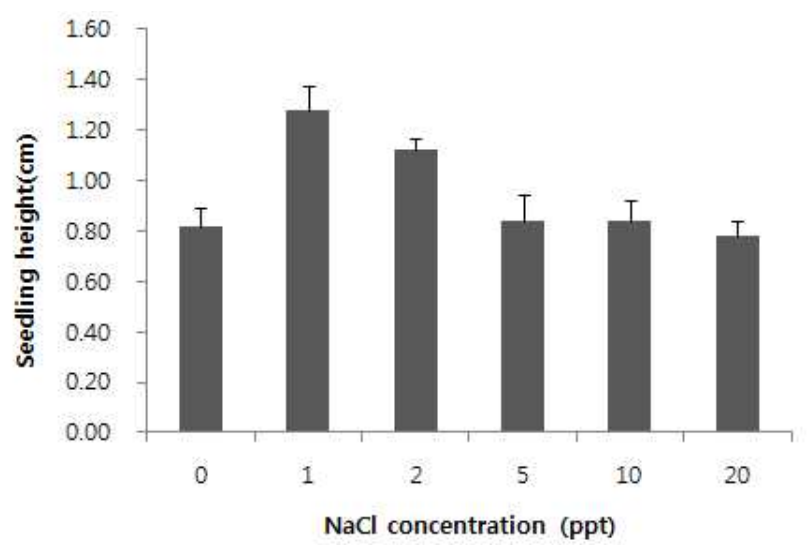

Fig. 6. Growth measurements of two-week-old Suaeda japonica seedlings on $1 / 2$ MS media containing 0 ppt, 1 ppt, 2 ppt, 5 ppt, 10 ppt and 20 ppt $\mathrm{NaCl}$. Bars indicate standard errors $(n=30)$

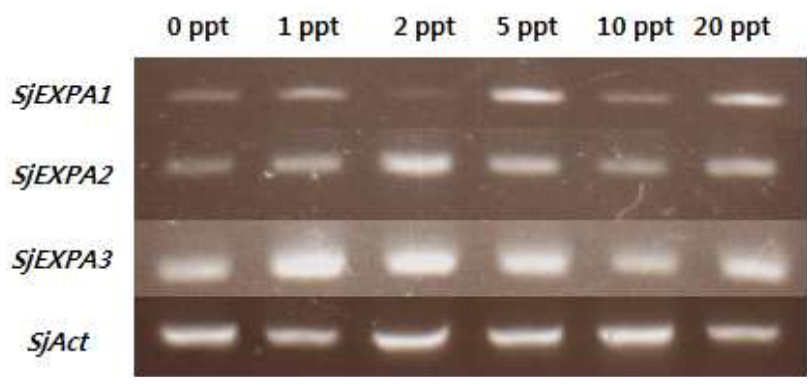

Fig. 7. Expression pattern of SjEXPA genes under increasing concentrations of $\mathrm{NaCl}(0$ ppt, 1 ppt, 2 ppt, 5 ppt, 10 ppt and 20 ppt). Semi-quantitative RT-PCR was conducted with SjAct as an internal control. Results are representative of those from repeated experiments.

차이를 나타내지 않았으나 $1 \mathrm{ppt}$ 와 $2 \mathrm{ppt}$ 처리구에서 가장 높은 생장도를 보였다(Fig. 6). 각 $\mathrm{NaCl}$ 농도에서 유식물의 평 균 초장은 $0.82 \mathrm{~cm}(0 \mathrm{ppt}), 1.28 \mathrm{~cm}(1 \mathrm{ppt}), 1.12 \mathrm{~cm}(2 \mathrm{ppt})$, $0.84 \mathrm{~cm}(5 \mathrm{ppt}), 0.84 \mathrm{~cm}(10 \mathrm{ppt})$ 및 $0.78 \mathrm{~cm}(20 \mathrm{ppt})$ 로 측정되 
었다. $\mathrm{NaCl}$ 농도에 따른 expansin 유전자의 발현을 확인하기 위해 semi-quantitative RT-PCR을 수행한 결과 expansin 유전 자의 발현은 $\mathrm{NaCl}$ 농도의 영향을 받지 않고 발현됨을 확인하 였다(Fig. 7).

\section{고 찰}

본 연구에서는 염생식물에서는 최초로 칠면초(Suaeda japonica)의 expansin 유전자의 cDNA 3종을 분리하였으며, 이 를 이용하여 칠면초 EXPA 단백질 3 종의 1 차구조와 각 유전자 의 발현양상을 분석하였다.

분리한 3종의 칠면초 expansin cDNA 염기서열 분석 및 단 백질 1차 구조의 비교분석 결과 시스테인 잔기의 위치 및 배열 간격과 트립토판의 위치, 그리고 활성부위의 일부로 생각되는 $\mathrm{HFD}$ 도메인이 잘 보존되어 있다는 점에서 이들이 a- expansin (EXPA)에 속한다는 것을 알 수 있었다(Fig. 1).

애기장대, 벼, 옥수수, 딸기, 토마토, 담배, 고사리, 이끼와 대추나무에서 밝혀진 expansin 단백질과 칠면초의 expansin 단백질을 대상으로 계통수를 작성한 결과 SjEXPA1과 SjEXPA3는 딸기의 expansin과 가까우며 SjEXPA2는 대추나 무 expansin과 가장 가까운 것으로 나타났다(Fig. 2). 목본인 대추나무 및 목본성의 딸기와 계통적으로 가까운 것으로 나타 나는 이유는 칠면초의 생육특성과 관련이 있는 것으로 생각된 다. 칠면초는 일년생 초본이지만 생육초기에는 초본성으로 자 라다가 나중에 목질화되는 경향이 있다. 따라서 칠면초의 expansin이 목본 식물의 expansin과 유사한 기능을 가질 것으로 추측할 수 있으며 이는 단백질 구조의 유사성과 밀접한 관계 가 있다고 볼 수 있다. 이의 확인을 위하여 생육 단계별 expansin 유전자의 발현양상 변화를 추적하는 실험이 차후 필요 할 것이다.

칠면초의 기관별 expansin 유전자의 발현양상을 알아본 결 과 SjEXPA1과 SjEXPA2는 모든 기관에서 발현되었으며, SjEXPA3는 뿌리에서 발현되지 않는 것을 확인하였다(Figs. 4, 5). 줄기와 잎에서는 모든 expansin 유전자가 발현되지만 SjEXPA1과 SjEXPA3은 SjEXPA2 유전자에 비하여 잎에서 발 현량이 적은 것으로 나타났다(Fig. 4). 줄기에서 모든 expansin 유전자가 발현되고 발현량도 다른 기관에 비하여 많은 이유는 줄기에 위치한 분열조직의 영향인 것으로 생각된다. 뿌리에서 도 expansin 유전자의 발현량이 많을 것이라고 추측되지만 비교적 발현량이 적은 이유는 뿌리 특이적인 expansin 유전자 가 따로 존재함에도 불구하고 본 연구에서 분리하지 못한데 있다고 생각된다. 벼의 경우 뿌리 특이적인 expansin 유전자가 분리되어 연구된 바 있으며 콩의 경우에도 뿌리 특이적인 expansin 유전자의 발현이 뿌리의 생장도와 밀접하게 관련되어 있다는 증거가 제시된 바 있다 $[2,17]$. 따라서 칠면초에도 뿌리
생장과 밀접하게 관련된 expansin이 존재할 가능성이 있다. 향후 칠면초의 뿌리 특이적 expansin 유전자의 분리를 통하여 칠면초의 뿌리 생장에 있어서 expansin의 역할을 구명해야 할 것이다.

내염성이 없는 식물의 경우 일반적으로 고염도 환경에서 생장이 저해되는데 이는 expansin과 같은 생장 관련 유전자의 발현이 저해된 결과일 것으로 생각된다. 최근의 한 보고에 의 하면 내염성 옥수수의 경우 고염도 환경에서도 식물이 정상적 으로 생장하고 expansin 유전자도 염분농도와 무관하게 일정 하게 발현된다. 그러나 내염성이 없는 정상 옥수수의 경우에 는 고염도 환경에서 생장이 저해될 뿐만 아니라 expansin 유 전자 발현도 현저하게 줄었다[24]. 고염도 환경에서의 칠면초 유식물의 생육 실험결과에 따르면 실험에 사용된 $\mathrm{NaCl}$ 농도 범위 $(0,1,2,5,10$ 및 $20 \mathrm{ppt})$ 내에서 유식물의 생장이 현저하게 억제되지 않았을 뿐만 아니라 expansin의 발현량에도 큰 변 화가 없었다(Figs. 6, 7). 이 결과로 미루어 내염성을 가진 식물 이 고염도 환경에서도 정상적으로 생장할 수 있는 이유 중 하나로 expansin과 같은 생장관련 유전자의 발현이 $\mathrm{NaCl}$ 의 농도에 크게 영향을 받지 않고 정상적으로 유지됨으로써 식물 의 생장 저하가 일어나지 않도록 할 것이라는 점을 들 수 있다. SjEXPA1의 경우 다른 expansin 유전자들과 달리 염분 농도의 증감에 따라 발현량이 일정하지 않지만 SjEXPA2와 SjEXPA3 의 경우 발현량이 일정하게 유지되었다(Fig. 7). 또한 SjEXPA2 와 SjEXPA3의 발현이 SjEXPA1보다 월등히 강한 것으로 보아 염분 환경에서의 칠면초 유식물 생장에는 SjEXPA2와 SjEXPA3 두 유전자가 중요한 역할을 할 것으로 사료된다. 이를 증명하 기 위해서는 expansin 유전자를 과다발현 시키거나 억제하도 록 조절된 형질전환 칠면초를 이용한 실험이 필요하다. 그러 나 칠면초의 유전자 조작에 관한 연구는 아직까지 이루어진 바 없기 때문에 앞으로 많은 노력과 연구가 필요하다.

본 연구의 결과로 염생식물인 칠면초가 고염도 환경에서 정상적으로 생육할 수 있도록 하는데 expansin이 중요한 요 소 중 하나일 것이라고 결론지을 수 있다. 최근 들어 염생식물 이 정화능력을 가지고 있으며 해안 염습지의 침식을 방지하 는데 효과적으로 사용될 수 있을 뿐만 아니라 생리활성물질 을 다량 함유하고 있다는 점이 알려지면서 많은 관심을 끌고 있다. 염생식물의 보존 및 활용을 위해서 활발한 분자생물학 적 연구가 필요하다. 따라서 칠면초 expansin 유전자의 기능 에 대한 연구는 염생식물의 응용에 대한 기초연구로서 중요 한 의미를 가진다.

\section{감사의 글}

이 논문은 2010년 한국연구재단 일반연구자지원사업(과제 번호: 2010-0023667) 지원에 의한 연구결과임. 


\section{References}

1. Anjanasree, K. N. and Bansal, K. C. 2003. Isolation and characterization of ripening-related expansin cDNA from tomato. J Plant Biochem Biotechnol 12, 31-35.

2. Cho, H. T. and Cosgrove, D. J. 2002. Regulation of root hair initiation and expansin gene expression in Arabidopsis. Plant Cell 14, 3237-3253.

3. Cho, H. T. and Cosgrove, D. J. 2004. Expansins as agents in hormone action. pp. 262-281. In Davies, P. J. (ed.), Plant Hormones 3rd edn. Kluwer Academic, Dordrecht.

4. Cho, H. T. and Kende, H. 1997a. Expansins in deepwater rice inter-nodes. Plant Physiol 113, 1137-1143.

5. Cho, H. T. and Kende, H. 1997b. Expansins and internodal growth of deepwater rice. Plant Physiol 113, 1145-1151.

6. Cho, H. T. and Kende, H. 1997c. Expression of expansin genes is correlated with growth in deepwater rice. Plant Cell 9, 1661-1671.

7. Choi, D., Cho, H. T. and Lee, Y. 2006. Expansins: expanding importance in plant growth and development. Plant Physiol 126, 511-518.

8. Choi, D. 2007. Ethylen-induced stem growth of deepwater rice is correlated with expression of gibberellin- and abscisic acid-biosynthetic genes. I Plant Biol 50, 595-599.

9. Choi, J. I., Kim, Y. J., Kim, J. H., Song, B. S., Yoon, Y., Byun, M. W., Kwon, J. H., Chun, S. S. and Lee, J. W. 2009. Antioxidant activities of the extract fractions from Suaeda japonica. J Korean Soc Food Sci Nutr 38, 131-135.

10. Cosgrove, D. J. 1998. Cell wall loosening by expansins. Plant Physiol 118, 333-339.

11. Cosgrove, D. J. 2000. Loosening of plant cell walls by expansins. Nature 407, 321-326.

12. Gao, X., Liu, K. and Lu, Y. T. 2010. Specific roles of AtEXPA1 in plant growth and stress adaptation. Russ. J Plant Physiol 57, 241-246.

13. Hiwasa, K., Rose, J. K. C., Nakano, R., Inaba, A. and Kubo, Y. 2003. Differential expression of seven alpha-expansin genes during growth and ripening of pear fruit. Plant Physid $117,564-572$.

14. Kende, H., Bradford, K., Brummell, D., Cho, H. T., Cosgrove,
D. J., Fleming, A., Gehring, C., Lee, Y., McQueen-Mason, S. M., Rose, J. K. C. and Voesenek, L. A. 2004. Nomenclature for members of the expansin superfamily of genes and proteins. Plant Mol Biol 55, 311-314.

15. Kim, J. H., Cho, H. T. and Kende, H. 2000. a-Expansins in the semiaquatic ferns Marsilea Quadrifolia and Regnellidium diphyllum evolutionary aspects and physiological role in rachis elongation. Planta 212, 85-92.

16. Kim, Y. A., Um, Y. R., Lee, J. I., Kim, H. J., Lim, S. Y., Nam, T. J. and Seo, Y. W. 2009. Comparative studies on the fatty acid compositions of the korean salt marsh plants in the west sea. Korean J Biotechnol Bioeng 24, 521-526.

17. Lee, D. K., Ahn, J. H., Song, S. K., Choi, Y. D. and Lee, J. S. 2003. Expression of an expansin gene is correlated with root elongation in soybean. Plant Physiol 131, 985-997.

18. Lee, H. J., Kim, Y. A., Ahn, J. W., Lee, B. J., Moon, S. G. and Seo, Y. 2004. Screening of peroxynitrite and DPPH radical scavenging activities from salt marsh plants. Korean $J$ Biotechnol Bioeng 19, 57-61.

19. Lee, Y., Choi, D. and Kende, H. 2001. Expansins: ever-expanding numbers and functions. Curr Opin Plant Biol 2001 4, 527-532.

20. Lee, Y. and Kende, H. 2002. Expression of alpha-expansin and expansin-like genes in deepwater rice. Plant Physiol 130, 1396-1405.

21. Min, B. M. 1998. Vegetation on the west coast of Korea. Ocean Polar Res 20, 167-178.

22. Mim, B. M. 2005. Seed distribution and burial properties of Suaeda japonica in tidal-flat. J Ecol Field Biol 28, 141-147.

23. Mühling, K. H. and Läuchli, A. 2002. Effect of salt sterss on growth and cation compartmentation in leaves of two plant species differing in salt tolerance. Plant Physiol 159, 137-146.

24. Pitann, B., Zorb, C. and Mühling, K. H. 2009. Comparetive proteome analysis of maize (Zea mays L.) expansins under salinity. J Plant Nutr Soil Sci 172, 75-77.

25. Rose, J. K. C., Lee, H. H. and Bennett, A. B. 1997. Expression of a divergent expansin gene is fruit-specific and ripening-regulated. Proc Natl Acad Sci USA 94, 5955-5960. 


\section{초록 : 칠면초(Suaeda japonica) expansin 유전자의 분리 및 특성 분석}

황숭택 · 김석규 · 나종길 · 이점숙 · 최동수*

(국립군산대학교 자연과학대학 생물학과)

본 연구에서는 염생식물에서는 최초로 expansin 유전자를 분리하고 특성을 분석하였다. 염생식물 중 생리활성 물질 등으로 최근 들어 관심의 대상이 되고 있는 칠면초로부터 expansin 유전자의 cDNA 3종을 분리, 합성하였 다. 확보한 3 종의 칠면초 expansin cDNA 염기서열 분석 및 단백질 1 차 구조의 비교분석 결과 시스테인 잔기의 위치 및 배열간격과 트립토판의 위치, 그리고 활성부위의 일부로 생각되는 HFD 도메인이 잘 보존되어 있다는 점에서 이들이 a- expansin (EXPA)에 속한다는 것을 확인하였다. 다른 식물들과 칠면초의 expansin 단백질을 대 상으로 계통수를 작성한 결과, 목본성인 딸기와 대추나무의 expansin과 가장 가까운 것으로 나타났다. 칠면초는 일년생 초본이지만 생육초기에는 초본성으로 자라다가 나중에 목질화되는 경향이 있다. 따라서 칠면초의 expansin이 목본 식물의 expansin과 유사한 기능을 가질 것으로 추측할 수 있다. 고염도 환경에서의 칠면초 유식물 의 생육 실험결과에 따르면 실험에 사용된 $\mathrm{NaCl}$ 농도범위 내에서 유식물의 생장이 현저하게 억제되지 않았을 뿐만 아니라 expansin의 발현량에도 큰 변화가 없었다. 이 결과로 미루어 내염성을 가진 식물에서는 expansin과 같은 생장관련 유전자의 발현이 $\mathrm{NaCl}$ 의 농도에 크게 영향을 받지 않으므로 식물의 생장이 저해되지 않는다고 유추할 수 있다. 이는 염생식물인 칠면초가 고염도 환경에서 정상적으로 생육할 수 있도록 하는데 expansin이 중요한 요소 중 하나일 것이라는 점을 의미한다. 